\title{
PEMBELAJARAN BAHASA INGGRIS DENGAN METODE BLENDED- LEARNING BAGI CALON ROHANIAWAN DI JAKARTA
}

\author{
J. Sandra Sembel' ${ }^{1}$, Dwi Y. Nugroho² ${ }^{2}$ Michael R. Sihombing ${ }^{3}$ \\ Dina V. Silaban ${ }^{4}$, Shally R. Gultom ${ }^{5}$ \\ ${ }^{1-5}$ Universitas Pelita Harapan, Lippo Karawaci
}

sandra.sembel@uph.edu,dwi.nugroho@uph.edu,michael.recard@uph.edu

\begin{abstract}
Abstrak
Para rohaniawan perlu mengembangkan kemampuan berkomunikasi yang baik untuk melayani umat dan masyarakat sekitar dimana mereka ditempatkan. Sekolah Tinggi Teologia (STT) Pelita Bangsa Jakarta sebagai lembaga pendidikan bagi calon rohaniawan berkeinginan untuk mengakomodasi kebutuhan pengembangan kemampuan berkomunikasi peserta didik. Kebutuhan tersebut didukung oleh lokasi sekolah tinggi yang berada di Jakarta sebagai kota metropolitan yang menampung penduduk dari berbagai latar belakang budaya dan bangsa, termasuk masyarakat internasional yang berasal dari berbagai negara. Oleh karena itu, para calon rohaniawan perlu mengembangkan kemampuan berkomunikasi dalam bahasa Inggris sebagai bahasa internasional. Hal tersebut menjadi latar belakang tim Pengabdian kepada Masyarakat (PkM) Universitas Pelita Harapan (UPH) untuk mengakomodasi kebutuhan pembelajaran bahasa Inggris tingkat dasar bagi calon rohaniawan Kristiani di STT Pelita Bangsa untuk mendukung misi pelayanan mereka. Kegiatan pembelajaran diberikan dalam 16 sesi dengan menggunakan metode blended learning, yaitu kombinasi antara pembelajaran tatap muka dan pembelajaran elektronik dengan memanfaatkan teknologi. Pemanfaatan teknologi dalam pembelajaran, membantu peserta untuk tetap dapat mengembangkan kemampuan tersebut di tengah kesibukan pelayanan mereka. Di akhir kegiatan, para peserta didik berhasil meningkatkan percaya diri mereka dalam berkomunikasi menggunakan bahasa Inggris dan dapat mendemonstrasikan kemampuan berbahasa Inggris di tingkat dasar untuk memberikan penjelasan singkat dan bercakap-cakap dalam bahasa Inggris mengenai topik sehari-hari.
\end{abstract}

Kata Kunci: Komunikasi, pembelajaran bahasa Inggris, tingkat dasar, blended learning

\section{PENDAHULUAN}

Mereka yang terpanggil untuk menjadi rohaniawan memiliki satu tujuan utama yakni membimbing umat yang mereka layani dan masyarakat sekitar tempat pelayanan mereka untuk menjadi semakin bertumbuh dalam iman mereka. Tugas para rohaniawan ini adalah mendukung misi pelayanan dalam lingkup keyakinan mereka. Menurut Widiatmadja (2009), misi pelayanan rohaniawan Kristiani mencakup tiga ranah yaitu koinonia (bersekutu), marturia (bersaksi) dan diakonia (melayani). Komunikasi merupakan aspek penting dalam menjalani berbagai pelayanan di tiga ranah ini. Oleh karena itu, para rohaniawan diharapkan mempunyai ketrampilan berkomunikasi yang baik.

Menurut Dr. Samina Dazdarević dalam artikelnya berjudul English for Religious Purposes, penguasaan bahasa adalah bagian penting dari kompetensi komunikasi bagi para rohaniawan Kristen (Dazdarević, 2012). Komunikasi diperlukan

$$
\text { Pendidikan }
$$


untuk menjangkau dan berinteraksi dengan warga gereja dan warga sekitar gereja. Dalam komunikasi dan interaksi, terutama di era informasi ini, dan di kota-kota besar seperti Jakarta, kemampuan menguasai bahasa asing, terutama bahasa Inggris, menjadi sangat penting. Penguasaan bahasa Inggris dapat membantu para rohaniawan untuk berkomunikasi untuk memberitakan pengajaran agama dan keimanan mereka. Kemampuan berbahasa Inggris dapat membantu membuka kesempatan untuk berinteraksi dengan lebih banyak orang dari latar belakang budaya dan bangsa yang berbeda, termasuk warga asing yang ada di lingkungan gereja. Kemampuan berbahasa Inggris juga membuka kesempatan bagi para rohaniawan dan calon rohaniawan untuk meningkatkan pengetahuan mereka melalui berbagai buku referensi yang diperlukan guna mendukung pengembangan diri dan pelayanan mereka.

Sebagai sebuah institusi teologia, Sekolah Tinggi Teologia (STT) Pelita Bangsa Jakarta selalu berusaha mempersiapkan mahasiswanya untuk menjadi seorang rohaniawan Kristen yang kompeten dan profesional. Mahasiswa STT Pelita Bangsa Jakarta diharapkan juga memiliki kesempatan untuk belajar mengembangkan kemampuan berkomunikasi, terlebih komunikasi dalam bahasa Inggris. Selain untuk mendukung pelayanan mereka dengan umat nantinya, kemampuan untuk berkomunikasi dalam bahasa Inggris sangat diperlukan oleh mahasiswa karena lokasi institusi yang berada di Jakarta sebagai kota metropolitan di mana umat yang dilayani berasal dari berbagai macam negara. Akan tetapi, STT Pelita Bangsa belum cukup mempunyai tenaga pendidik bahasa Inggris sehingga kegiatan pembelajaran bahasa Inggris masih sangat dibutuhkan dan bantuan dari pihak luar STT Pelita Bangsa sangat dibutuhkan. Kebutuhan akan pembelajaran bahasa Inggris dan keadaan institusi inilah yang melatar-belakangi tercetusnya kerjasama dalam bentuk kegiatan Pengabdian kepada Masyarakat $(\mathrm{PkM})$ yang dilaksanakan oleh tim PkM Universitas Pelita Harapan (UPH). Kegiatan PkM ini diharapkan dapat memfasilitasi mahasiswa STT Pelita Bangsa Jakarta dalam mengembangkan ketrampilan berkomunikasi mereka dalam bahasa Inggris.
Para calon rohaniawan yang mengikuti kegiatan PkM ini dipersiapkan untuk pelayanan umat. Mereka berasal dari berbagai pelosok Indonesia dan sebagian besar diutus dan disponsori untuk belajar dengan beasiswa penuh di STT Pelita Bangsa Jakarta. Karena akses untuk belajar dan berlatih bahasa Inggris di tempat asal mereka sangat terbatas, para calon rohaniawan ini memiliki kemampuan berbahasa Inggris yang sangat terbatas, bahkan hampir separuh dari mereka tidak bisa berbahasa Inggris sama sekali.

Dari hasil analisis kebutuhan yang melibatkan wawancara dengan ketua lembaga pendidikan tinggi teologia swasta tersebut, ditemukan bahwa, para calon rohaniawan memiliki kemampuan berbahasa Inggris tingat pemula. Karena keterbatasan mereka dalam penguasaan Bahasa Inggris, para calon rohaniawan sulit memahami berbagai literatur terkait pendidikan mereka yang dicetak dalam Bahasa Inggris. Selain itu, mereka memiliki rasa percaya diri yang rendah ketika mereka harus belajar untuk memberikan pelayanan bagi warga gereja dan warga asing di sekitar mereka. Oleh karena itu perlu adanya pelatihan bahasa Inggris yang sesuai dengan kebutuhan peserta dengan metode yang sudah teruji manfaatnya.

$\mathrm{PkM}$ ini bertujuan untuk membantu menyelesaikan permasalahan keterbatasan penguasaan bahasa Inggris dan rasa percaya diri dalam menggunakan bahasa Inggris melalui pembelajaran Bahasa Inggris tingkat dasar. Paket pembelajaran dasar ini diberikan dalam 16 sesi, menggunakan metode blended learning, yaitu memanfaatkan teknologi pembelajaran jarak jauh secara daring dengan bantuan komputer yang dipadu dengan metode pembelajaran tatap muka (Bonk \& Graham, 2012). Menurut Neumeir (2005, dalam Ghiffar et. Al, 2018), hal utama dari metode blended learning adalah untuk menggabungkan beberapa metode pembelajaran yang paling efektif sesuai dengan karakteristik peserta didik, konteks, dan tujuan pembelajaran. Ghiffar et.al (2018) menyimpulkan bahwa blended learning terjadi karena proses yang terstruktur dari penggabungan metode pembelajaran tatap muka yang dinilai sebagai metode tradisional dan metode pengajaran menggunakan teknologi yang dinilai sebagai metode baru. Yen dan Lee (2011) berpendapat bahwa bila elemen-elemen terbaik dari

$$
\text { Pendidikan } 714
$$


pembelajaran daring dan tatap muka digabungkan, maka pembelajaran dengan metode blended learning menjadi model pembelajaran yang unggul di masa yang akan datang. Dengan demikian, dapat kita simpulkan bahwa metode blended learning dipilih untuk membantu peserta didik dalam mencapai tujuan belajar melalui lebih dari satu jenis metode pembelajaran. Oleh karena itu, metode blended learning diharapkan mampu untuk membantu peserta PkM ini dalam berkomunikasi menggunakan bahasa Inggris melalui metode pembelajaran yang bukan hanya efektif, tetapi juga memanfaatkan teknologi yang berkembang saat ini.

Selain itu, metode blended learning dipilih karena pendidikan tinggi diharapkan mampu mempersiapkan peserta didik untuk menghadapi era revolusi industri 4.0. Muhali (2018) berpendapat bahwa ada tiga literasi baru yang diperlukan sumber daya manusia di masa depan, yakni literasi data, literasi teknologi, dan literasi kemanusiaan. Penggunaan metode blended learning dalam PkM ini diharapkan juga mampu mempersiapkan calon peserta didik untuk menghadapi revolusi industri 4.0.

Pengajaran menggunakan blended learning pun sudah mendapatkan perhatian dari para akademisi. Dengan melibatkan 1431 siswa sebagai responden, penelitian yang dilakukan oleh López-Pérez dan Rodríguez-Ariza (2011) menunjukan hasil bahwa metode blended learning dapat meningkatkan nilai mahasiswa dan dapat mengurangi jumlah mahasiswa yang dropout dari universitas. Penelitian eksperimental yang dilakukan oleh Alseweed (2013) menunjukan hasil yang serupa bahwa siswa yang belajar bahasa Inggris menggunakan metode blended learning mempunyai pencapaian yang lebih tinggi dibandingkan dengan pencapaian siswa yang belajar bahasa Inggris menggunakan metode tradisional dan kelas virtual. Selain itu, penelitian Poon (2013) menunjukan bahwa siswa merasa mendapatkan manfaat dari pembelajaran menggunakan metode blended learning, dan manfaat terbesar yang dirasakan oleh para siswa terkait dengan fleksibilitas mata kuliah karena mereka dapat merasakan gaya belajar yang beragam. Bonk \& Graham (2012) menyatakan bahwa sistem, pembelajaran jarak jauh menekankan pembelajaran yang memberi kesempatan kepada siswa untuk memilih kapan dan di mana mereka mau belajar (self-paced). Penelitian yang lebih terkini mengenai implementasi blended learning dilakukan oleh Juniarta, Eka, \& Sitanggang (2018) melalui penelitian untuk menggali pengalaman mahasiswa keperawatan menggunakan metode blended learning. Penelitian mereka mengungkapkan bahwa kebanyakan mahasiswa yang terlibat dalam penelitian mereka (>70\%) memberikan penilaian yang positif terhadap metode blended learning. Ghiffar et. al. (2018) menambahkan bahwa metode blended learning merupakan metode yang menjanjikan bila pengajar ingin meningkatkan kemampuan berpikir kritis para peserta didik. Dengan demikian, dapat disimpulkan bahwa metode blended learning adalah metode pembelajaran yang memberikan manfaat dan pengalaman yang baik bagi peserta didik sesuai dengan tuntutan pembelajaran yang mempersiapkan para peserta didik untuk menghadapi era revolusi industri 4.0..

Dengan melihat kebutuhan peserta PkM ini dengan disesuaikan dengan metode belajar zaman ini, tim PkM melaksanakan program pengabdian kepada masyarakat bagi calon rohaniawan di STT Pelita Bangsa Jakarta. Makalah ini akan menjelaskan bagaimana kegiatan PkM ini terlaksana, hasil kegiatan PkM, serta saran yang bisa dikemukakan dari kegiatan PkM ini.

\section{METODE}

Untuk mendukung tercapainya tujuan dari program PkM ini, tim melakukan langkah-langkah berikut:

\section{Tahap 1. Analisis Kebutuhan Belajar}

Pada tahap ini dilakukan wawancara terhadap pengurus sekolah tinggi swasta tempat para calon rohaniawan dididik. Dari pertemuan ini didapatkan informasi berikut:

Profil Peserta: Peserta yang memerlukan pembelajaran bahasa Inggris adalah siswa tahun pertama di STT Pelita Bangsa yang mendapat beasiswa dari gereja masing-masing untuk belajar di sekolah tinggi tersebut. Para peserta yang awalnya berjumlah 12 orang berasal dari berbagai latar belakang budaya dan dari berbagai pulau di Indonesia, antara lain: Sumatera (terutama Sumatera Utara), Kalimantan, dan Jawa. Setelah beberapa sesi

$$
\text { Pendidikan }
$$

715 
pembelajaran berjalan, ada 3 tambahan peserta yang masuk dan 1 peserta yang mengundurkan diri. Total peserta yang menyelesaikan program ini sampai akhir berjumlah 14 orang.

Tabel 1. Peserta Kegiatan

\begin{tabular}{llc}
\hline No & \multicolumn{1}{c}{ Status } & Jumlah \\
\hline 1. & $\begin{array}{l}\text { Peserta di awal } \\
\text { pembelajaran }\end{array}$ & 12 \\
2. & $\begin{array}{l}\text { Peserta yang } \\
\text { bergabung setelah } \\
\text { beberapa sesi yang }\end{array}$ & 3 \\
3. & $\begin{array}{l}\text { Peserta } \\
\text { mengundurkan diri }\end{array}$ \\
\hline 4. & $\begin{array}{l}\text { Peserta didik yang } \\
\text { ikut sampai akhir }\end{array}$ & 14 \\
\hline
\end{tabular}

Identifikasi masalah: Para peserta memiliki dua masalah utama, yakni: (1) Rendahnya tingkat percaya diri ketika harus menggunakan bahasa Inggris, dan (2) kemampuan berkomunikasi dalam bahasa Inggris yang sangat dasar bahkan ada beberapa yang sama sekali tidak bisa berbahasa Inggris.

Kebutuhan belajar peserta: Dari hasil identifikasi masalah dapat diformulasikan kebutuhan utama peserta, yaitu kebutuhan untuk meningkatkan rasa percaya diri untuk menggunakan bahasa Inggris dan kemampuan berbicara dalam bahasa Inggris untuk terlibat dalam percakapan sehari-hari untuk membangun komunikasi dengan warga asing di seputar lingkungan mereka masing-masing.

\section{Tahap 2. Persiapan Kegiatan}

Informasi yang didapatkan dari analisis kebutuhan belajar digunakan untuk melakukan persiapan yang diperlukan untuk mendukung pelaksanaan PkM ini. Ada tiga hal yang dipersiapkan oleh tim PkM, yakni persiapan materi pembelajaran, persiapan platform pembelajaran, serta persiapan dokumen pendukung pembelajaran.

Pada tahap persiapan yang pertama, tim PkM mempersiapkan materi pembelajaran. Materi pembelajaran utama berupa model dialogs dan berbagai kegiatan untuk meningkatkan kosakata bahasa Inggris. Materi-materi tersebut disampaikan dalam bentuk softcopy untuk pembelajaran mandiri yang diunggah di blog pembelajaran bahasa Inggris untuk para peserta. Selain untuk memotivasi mahasiswa dalam belajar mandiri, hal ini diharapkan dapat membuat mahasiswa bekerja sama dalam kelompok kecil untuk membantu satu sama lain. Gambar 1 berikut menunjukan gambar blog yang dipakai untuk unggah materi.

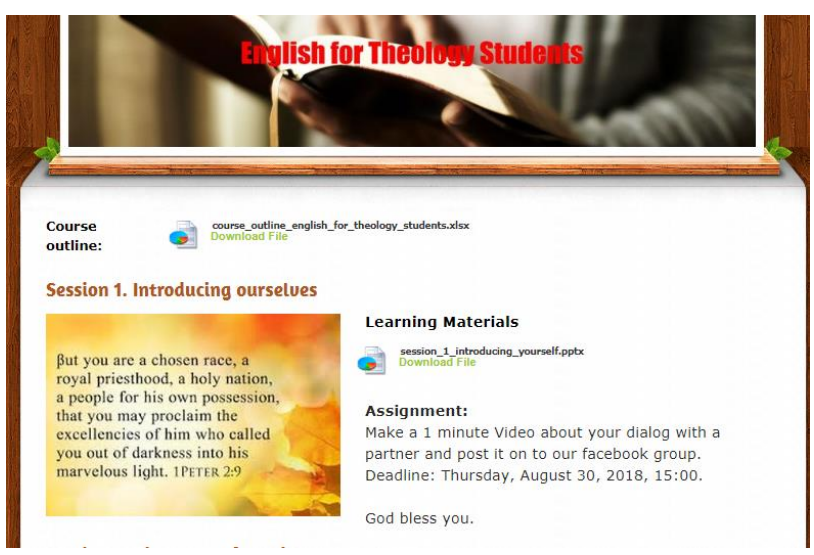

Gambar 1. Blog Pembelajaran

Setelah materi pembelajaran siap, persiapan yang dilakukan oleh tim PkM adalah persiapkan platform pembelajaran yang digunakan sebagai media pembelajaran selain blog yang telah disebutkan di atas. Platform lain yang digunakan dalam PkM ini adalah Facebook dan Whatsapp Group. Gambar 2 berikut menunjukan platform berbasis teknologi berupa Facebook yang digunakan dalam kegiatan PkM yang menggunakan metode blended learning ini.

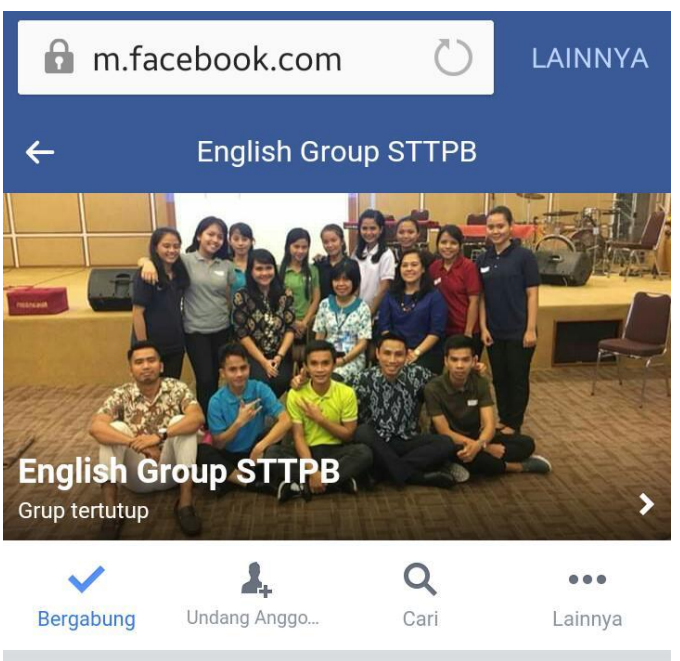

Gambar 2. Platform Facebook

Pendidikan 
Facebook dan Blog dipilih menjadi platform pembelajaran dikarenakan kedua platform tersebut mempunyai fitur-fitur yang memungkinkan pembelajaran bahasa Inggris dengan mentode blended learning berlangsung, seperti fitur unggah dokumen, fitur unggah foto dan video, dan fitur chat yang memungkinkan peserta PkM bertanya kepada fasilitator.

Selain itu, untuk mendukung komunikasi dengan peserta, tim juga menggunakan Whatsapp Group dan Facebook karena baik tim PkM maupun peserta kegiatan mempunyai akun di kedua aplikasi sosial media ini. Hal ini menunjukan bahwa baik peserta maupun fasilitator mempunyai pengetahuan yang cukup dalam menggunakan teknologi yang mendukung pembelajaran. Gambar 3 berikut menunjukan identitas grup Whatsapp yang dipakai untuk menunjang kegiatan PkM ini.

\section{Wr. PKM STT PELITA BANGSA Dina, Dwi UPH, Michael FoN2, Shally, You}

\section{Gambar 3. Platform Whatsapp Group}

Persiapan yang ketiga adalah persiapan dokumen pendukung pembelajaran. Dokumen-dokumen pendukung dalam kegiatan $\mathrm{PkM}$ ini antara lain, daftar hadir siswa serta jadwal pembelajaran daring dan jadwal pembelajaran tatap muka. Dokumen pembelajaran ini penting untuk dipersiapkan guna mendukung kegiatan pembelajaran bahasa Inggris menggunakan metode blended-learning. Dengan adanya tahap persiapan kegiatan ini, kegiatan PkM dapat terlaksana dan terdokomentasikan dengan baik hingga pada akhirnya peserta kegiatan ini dapat merasakan manfaatnya, terutama dalam hal meningkatkan motivasi dan percaya diri belajar bahasa Inggris maupun mengembangkan kemampuan bahasa Inggris.

\section{Tahap 3. Peluncuran Awal Program}

Ketika semua persiapan seelsai, tim PkM mempersiapkan acara pembukaan program dan sesi pertama tatap muka dengan peserta program. Gambar 4 berikut menunjukan kegiatan peluncuran awal program yang dihadiri seluruh peserta.

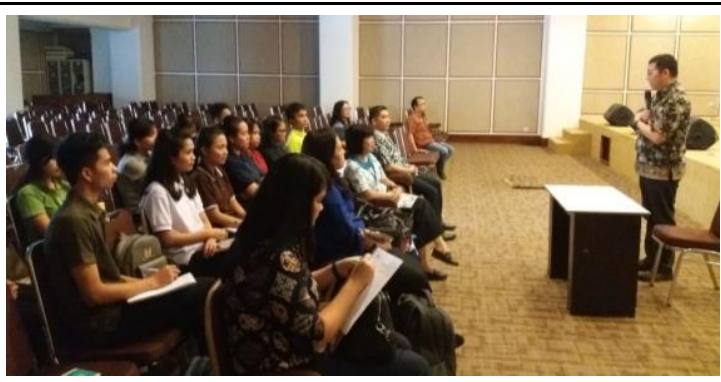

Gambar 4. Peluncuran awal program

Kegiatan peluncuran awal program ini juga dihadiri oleh pimpinan dan dosen dari STT Pelita Bangsa. Kegiatan ini bertujuan untuk menyamakan persepsi antara tim PkM, pihak STT Pelita Bangsa, dan peserta didik dalam hal tujuan pembelajaran, jadwal dan jenis kegiatan belajar-mengajar. Dengan adanya kesamaan persepsi ini, komunikasi dan kegiatan pembelajaran PkM dapat terakomodasi dengan baik dan tidak ditemukan adanya kesalahan komunikasi yang berarti yang dapat merugikan salah satu atau semua pihak.

\section{Tahap 4. Pelaksanaan Kegiatan PkM}

Pelaksanaan kegiatan dilakukan dengan jadwal berikut.

Tabel 2. Kegiatan Pembelajaran

\begin{tabular}{lll}
\hline No & $\begin{array}{l}\text { Kegiatan } \\
\text { Pembelajaran }\end{array}$ & Jumlah Sesi \\
\hline 1 & Pembelajaran online & 10 Sesi \\
2 & Pembelajaran offline & 4 Sesi \\
3 & $\begin{array}{l}\text { Ujian Tengah } \\
\text { Semester (tes } \\
\text { berbicara - Dialogs }\end{array}$ & \\
& $\begin{array}{l}\text { secara berpasangan) } \\
4\end{array}$ & \\
& $\begin{array}{l}\text { Ujian Akhir Semester } \\
\text { (tes berbicara - Mini }\end{array}$ & \\
& Drama Sesi dalam grup) & \\
\hline & Total & 16 Sesi \\
\hline
\end{tabular}

\section{Tahap 5. Penutupan Program}

Penutupan program dilakukan dengan melaporkan hasil pembelajaran serta pementasan mini-drama dalam bahasa Inggris oleh para peserta didik. Kegiatan penutupan ini dihadiri oleh perwakilan pihak STT Pelita Bangsa, tim PkM, dan peserta didik. 


\section{HASIL DAN PEMBAHASAN}

\section{Identifikasi Kebutuhan Belajar}

Sebelum proses pembelajaran dimulai, Tim PKM melakukan pertemuan dengan pimpinan STT Pelita Bangsa untuk mengidentifikasi kebutuhan belajar calon peserta didik. Hasil identifikasi kebutuhan belajar dapat dilihat di Tabel 3 .

Tabel 3. Identifikasi Kebutuhan Belajar Bahasa Inggris

\begin{tabular}{cll}
\hline No & \multicolumn{1}{c}{ Spesifikasi } & \multicolumn{1}{c}{ Keterangan } \\
\hline 1. & $\begin{array}{l}\text { Kompetensi } \\
\text { awal }\end{array}$ & Beginner dan Elementary \\
2. & $\begin{array}{l}\text { Keterampilan } \\
\text { bahasa yang } \\
\text { diperlukan }\end{array}$ & Berbicara (speaking) \\
3. $\begin{array}{l}\text { Cakupan topik } \\
\text { percakapan yang } \\
\text { diperlukan }\end{array}$ & $\begin{array}{l}\text { 8 topik utama (Personal } \\
\text { information, Daily } \\
\text { Activities, Families, } \\
\text { Jobs, Telling time, } \\
\text { numbers in our lives, } \\
\text { shopping, giving } \\
\text { information) }\end{array}$ \\
& $\begin{array}{l}\text { Cerita-cerita umum } \\
\text { dalam alkitab (mis: }\end{array}$ \\
K. & $\begin{array}{l}\text { Cakupan topik } \\
\text { penunjang } \\
\text { pembelajaran } \\
\text { teologi }\end{array}$ & $\begin{array}{l}\text { memberi makan } \text { Yesus, } \\
\text { orang, Petrus berjalan di } \\
\text { atas air, Zakeus, anak } \\
\text { yang hilang) }\end{array}$ \\
&
\end{tabular}

Hasil identifikasi kebutuhan bahasa Inggris menunjukkan bahwa sebagian besar peserta berada pada kompetensi awal tingkat beginners (pemula) dan elementary (dasar). Mereka membutuhkan bahasa Inggris untuk percakapan sehari-hari (speaking) dan membagikan cerita-cerita umum dalam alkitab (simple story-telling).

\section{Evaluasi Hasil Pembelajaran}

Evaluasi pembelajaran dilakukan dua kali. Pertama adalah evaluasi yang dilakukan di pertengahan proses pembelajaran. Evaluasi ini diberikan dalam bentuk Speaking Test, yaitu dialog antara 2 orang (pair-work) tentang topik percakapan sehari-hari. Sedangkan evaluasi lain dilakukan di akhir program, juga dalam bentuk oral test (Tes lisan) dalam kelompok.

Pada saat tes lisan, terutama saat ujian akhir semester, peserta didik terlihat cukup percaya diri dalam bercakap-cakap dalam bahasa Inggris. Mereka yang awalnya masih sangat malu berbicara dalam bahasa Inggris, bahkan dengan teman sekelas mereka, kini mereka memperlihatkan rasa percaya diri yang lebih tinggi dalam berbicara menggunakan bahasa Inggris. Gambar 5 berikut menunjukan penampilan peserta didik di depan teman-temannya.

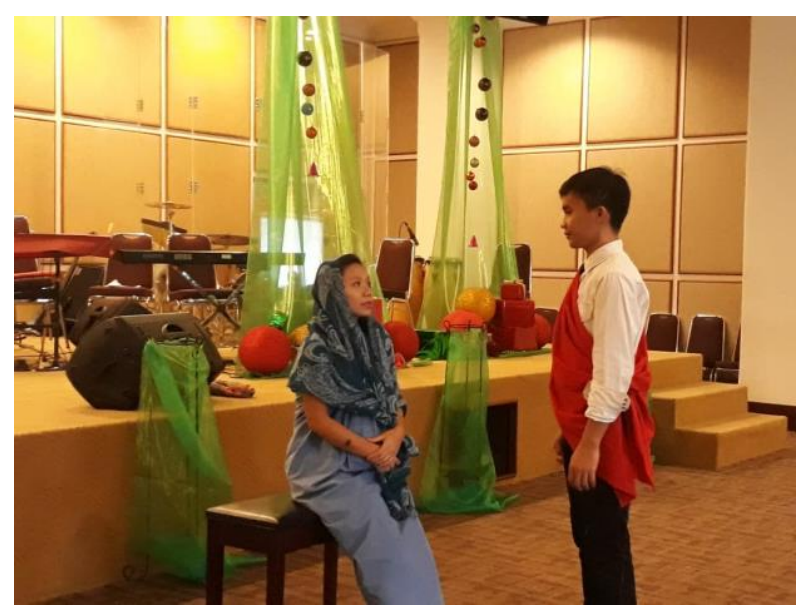

Gambar 5. Penampilan Peserta PkM

Mereka bercakap-cakap menggunakan bahasa Inggris membawakan cerita yang diambil dari Kitab Suci dengan cukup lancar dan percaya diri. Hal ini menunjukan peserta sudah lebih berani dan lebih akurat dalam menggunakan bahasa Inggris di depan umum.

Rincian dari jenis evaluasi dan hasilnya dapat dilihat di Tabel 4. 
Tabel 4. Hasil Ujian Tengah dan Akhir Semester

\begin{tabular}{cccl}
\hline Mahasiswa & $\begin{array}{l}\text { Ujian } \\
\text { Tengah } \\
\text { Semester }\end{array}$ & $\begin{array}{l}\text { Ujian } \\
\text { Akhir } \\
\text { Semester }\end{array}$ & $\begin{array}{l}\text { Pencapaian } \\
\text { Belajar }\end{array}$ \\
\hline 1 & 68 & 0 & (dropped \\
out) \\
2 & 74.5 & 82.5 & 8 \\
3 & 77.5 & 82.5 & 5 \\
4 & 71.75 & 91.5 & 19.75 \\
5 & 77.25 & 82.5 & 5.25 \\
6 & 87 & 91.5 & 4.5 \\
7 & 76.5 & 91.5 & 15 \\
8 & 81 & 82.5 & 1.5 \\
9 & 85 & 91.5 & 6.5 \\
10 & 68 & 91.5 & 23.5 \\
11 & 82.75 & 82.5 & -0.25 \\
12 & 78 & 91.5 & 13.5 \\
13 & 66 & 91.5 & 25.5 \\
14 & 65 & 82.5 & 17.5 \\
15 & 77 & 82.5 & 5.5 \\
Total & 1135.25 & 1218 & 82.75 \\
\hline Rata-Rata & 75.68 & 87 & 11.31 \\
\hline
\end{tabular}

Dari Tabel 4 di atas terlihat bahwa secara ratarata kompetensi peserta meningkat 11.31 poin dari perbandingan hasil ujian tengah semester dan ujian akhir semester, dengan peningkatan terbesar adalah 25.5 (Mahasiswa 13) dan peningkatan terkecil -0.25 (Mahasiswa 11). Hal ini menunjukan bahwa peserta didik dapat mendemonstrasikan kemampuan berbahasa Inggris di tingkat dasar untuk memberikan penjelasan singkat dan bercakap-cakap dalam bahasa Inggris mengenai topik sehari-hari.

\section{Evaluasi Partisipasi Kegiatan Daring dan Tatap Muka}

Kenaikan yang cukup signifikan ini (di atas 10 poin) diperkirakan karena partisipasi peserta yang tinggi bagi dalam kegiatan pembelajaran online maupun off-line, seperti yang terlihat dalam Tabel 5 berikut ini.
Tabel 5. Evaluasi Kegiatan Belajar Mengajar

\begin{tabular}{llll}
\hline No & $\begin{array}{l}\text { Ketera } \\
\text { ngan }\end{array}$ & Hasil & Analisis \\
\hline 1. & Partisip & Baik & Platform yang digunakan \\
& asi & Sekali & untuk kegiatan daring adalah \\
& kegiata & & Facebook dan blog yang \\
& n & & sudah dikenal dan dikuasai \\
& daring & & oleh para peserta yang \\
& & & usianya antara 17 - 19 tahun \\
& & (generasi millenial). Dengan \\
& & demikian mereka tidak \\
& & mengalami kendala berarti \\
& & menggunakan teknologi \\
& & terkait)
\end{tabular}

2. Partisip Baik Peserta difasilitasi oleh para asi Sekali fasilitator yang memiliki kegiata kemampuan bahasa Inggris n tatap tingkat 'advanced' yang muka terdiri dari beberapa dosen di UPH, dengan pengalaman mengajar lebih dari 2 tahun. Kegiatan sudah dirancang dengan pendekatan 'active learning', menggunakan variasi kegiatan yang kaya, baik dalam penyelesaian kegiatan pembelajaran (pair work, group work, individual work), maupun jenis kegiatan pembelajarannya (Modelling, information gap, pair interview, role play dan games).

3. Penyele Baik Dengan diunggahnya materi saian Sekali belajar mandiri di blog dan khusus, peserta dapat penyera mengakses dan han mempersiapkan diri sebelum tugas masuk kelas. Hal ini dirasa pre- $\quad$ sangat membantu.

study, Alat untuk memonitor study kegiatan belajar mandiri session siswa yang digunakan adalah dan lembar tugas/kerja yang post- perlu diselesaikan dan study diserahkan oleh peserta dengan jadwal penyelesaian dan penyerahan yang diinformasi kepada peserta secara reguler. 
Melalui hasil evaluasi belajar peserta didik dan evaluasi kegiatan belajar mengajar, hal ini menunjukan bahwa belajar bahasa Inggris melalui metode blended learning terlihat memberikan dampak yang positif bagi peserta didik. Akan tetapi, penelitian lebih lanjut mengenai efek metode blended learning masih perlu dilakukan agar hasil dapat lebih valid dan reliable.

\section{Tantangan yang Dihadapi}

Dalam pelaksanaan PkM ini, tim PkM mengalami tantangan. Tantangan terbesar yang dihadapi oleh tim PkM adalah kendala waktu. Terkadang tim PkM mengalami kendala saat hendak mengadakan kegiatan tatap muka dengan peserta didik. Hal ini disebabkan oleh kesibukan akademis tim PkM di institusi tempat mereka bekerja yang tidak bisa ditinggalkan dan juga kepadatan kegiatan para peserta. Akan tetapi, kendala ini dapat diselesaikan dengan baik karena adanya komunikasi yang lancar baik antara tim PkM dengan peserta didik, tim PkM dengan pimpinan STT Pelita Bangsa, maupun pimpinan STT Pelita Bangsa dengan peserta didik. Kegiatan tatap muka beberapa kali dilaksanakan di luar jam kerja, misalnya di hari Sabtu, atas kesepakatan semua pihak.

\section{KESIMPULAN}

Kegiatan paket belajar bahasa Inggris tingkat dasar bagi warga STT Pelita Bangsa ini berjalan cukup lancar dengan sedikit penyesuaian dalam jadwal pelaksanaan karena menyesuaikan dengan awal semester di STT Pelita Bangsa. Para peserta mendemonstrasikan antusiasme tinggi dalam pertemuan tatap muka dan juga dalam mengerjakan tugas-tugas mandiri secara daring. Dengan adanya peningkatan rasa percaya diri dan nilai hasil pembelajaran, tampak bahwa metode blended learning cukup membantu peserta dalam proses pembelajaran bahasa Inggris.

Selain itu, koordinasi antara tim PkM Fakultas Keperawatan UPH dengan pihak STT Pelita bangsa dalam pelaksanaan PkM ini juga berjalan dengan baik, terutama dalam penentuan jadwal peluncuran program, pelaksanaan kegiatan belajar-mengajar di kelas (off-line), serta penutupan program. Wakil dari STT Pelita Bangsa juga ikut hadi dalam peluncuran dan penutupan program. Pihak pimpinan STT Pelita Bangsa dan para peserta, di acara penutupan menyampaikan keinginan mereka agar paket belajar ini dilanjutkan ke tingkat yang lebih tinggi dengan topik yang lebih diperkaya dengan fokus pada keterampilan membaca dan menulis dalam bahasa Inggris.

Ada empat saran yang bisa disampaikan. Saran pertama terkait dengan metode pembelajaran bagi calon rohaniawan di STT Pelita Bangsa. Meskipun perlu diadakan penelitian lebih lanjut mengenai dampak pembelajaran bahasa Inggris dengan metode blended learning, pengajar di STT Pelita Bangsa dapat menggunakan metode ini dalam pembelajaran di mata kuliah reguler lainnya di institusi tersebut. Hal ini disebabkan pembelajaran blended learning tampak membuat peserta didik menjadi lebih antusias dan ketrampilan yang diperlukan di era revolusi industri 4.0. dapat diolah melalui pembelajaran dengan metode ini.

Saran yang kedua berkaitan dengan jadwal kegiatan pembelajaran tatap muka yang kadang berbenturan dengan kesibukan akademis tim PkM Fakultas Keperawatan UPH dan jadwal kegiatan di STT Pelita Bangsa. Untuk kelancaran penjadwalan kegiatan serupa di masa depan, disarankan agar penjadwalan dapat dilakukan secara bersama-sama dengan mengacu kepada kegiatan utama di kalender akademik masing-masing pihak sejak dari awal program.

Saran ketiga terkait keberlanjutan porgram. Pihak mitra sudah meminta kesediaan pihak tim PkM FoN UPH untuk keberlanjutan program sejenis dengan fokus Reading Skills dan Writing Skills. Untuk itu perlu dikaji kebutuhan pembelajaran selanjutnya, agar, jika memungkinkan program dilanjutkan, pembelajaran bisa didesain dengan materi dan kegiatan pembelajaran yang tepat sasaran sesuai dengan kebutuhan dan kesiapan belajar peserta.

Saran terakhir adalah pemberian pelatihan ToT (Training of trainers) bagi tenaga pengajar bahasa Inggris dari pihak STT Pelita Bangsa yang ditunjuk oleh pihak mitra untuk dilatih mendesain dan melanjutkan program sejenis. Kegiatan pelatihan bisa dilakukan secara tatap muka (misalnya 24 jam pelatihan: 8 jam pengenalan program, 8 jam desain program, 8 jam praktik pengajaran) ataupun blended learning ( 6 topik pelatihan: 4 secara daring

$$
\text { Pendidikan }
$$


yang mencakup teori pengenalan pembelajaran secara digital dan perancangan pembelajaran dan 2 topik secara tatap muka: pembuatan lesson plan dan praktik mengajar).

\section{UCAPAN TERIMAKASIH}

Tim PkM paket belajar Bahasa Inggris ini mengucapkan terimakasih kepada Universitas Pelita Harapan yang telah memberikan dukungan dana dan perizinan buntuk menyelesaikan kegiatan pengabdian kepada masyarakat ini dengan nomor proposal: PM-054-M/FoN/IX/2018.

\section{REFERENSI}

Alseweed, M.A. 2013. Students' Achievement and Attitudes towards Using Traditional Learning, Blended Learning, and Virtual Classes Learning in Teaching and Learning at the University Level. Studies in Literature and Language. 6(1), halaman 65-73.

Bonk, C.J. dan Graham, C.R. 2012. The Handbook of Blended Learning: Global perspective, local designs. San Fransisco: John Wiley \& Sons.

Dazdarević, S. 2012. English for Religious Purposes, Teaching foreign languages for special purposes, University for foreigners of Perugia, Italian language and culture. Conference proceeding.

Ghiffar, M.A.N, et. al. 2018. Model Pembelajaran Berbasis Blended Learning dalam
Meningkatkan Creative Thingking Skills untuk Menghadapi Era Revolusi Industri 4.0. Prosiding Seminar Nasional Pendidikan.

Juniarta., Eka., N.G.A., \& Sitanggang, Y. F. 2018. Nursing Students' Learning Experiences in an Online Learning Course. Nursing Current. 6(1), halaman 43-46.

López-Pérez, M.V. dan Rodríguez-Ariza, L. 2011. Blended learning in higher education: Students' perceptions and their relation to outcomes. Computers \& Education. 56(3), halaman 818-826.

Muhali. 2018. Arah Pengembangan Pendidikan Masa Kini Menurut Perspektif Revolusi Industri 4.0. Prosiding Seminar Nasional Lembaga Penelitian dan Pendidikan (LPP) Mandala.

Poon, J. 2013. Blended learning: an institutional approach for enhanching students' learning experiences. Journal of learning and teaching. 9(2), halaman 271-288.

Widiatmadja, Y.P. 2009. Diakonia Sebagai Misi Gereja. Yogyakarta: Kanisius.

Yen, J-C., \& Lee, C-Y. 2011. Exploring problem solving patterns and their impact on learning achievement in a blended learning environment. Computers \& Education, 56(1), halaman 138-145. 